\title{
Seed storage protein changes and mobilization pattern in Bambaranut (Vigna subterranea) (L.) Verdc. during germination
}

\author{
Najib M. Saminu \& Yusuf Y. Muhammad* \\ Department of Biochemistry, Bayero University, Kano, Nigeria \\ *Email: yymuhammad.bch@buk.edu.ng
}

ARTICLE HISTORY

Received: 12 May 2021

Accepted: 22 July 2021

Available online

Version 1: 30 August 2021

Version 2: 05 February 2022

\section{KEYWORDS}

Bambaranut

Landraces

Storage protein mobilization

Germination

Free amino acids

Endopeptidase

\begin{abstract}
The germination of seeds involves series of events during which mobilization and utilization of seed storage proteins occur. This study is aimed at determining the changes in total and fractions of seed storage protein in six bambaranut landraces during 96 hrs germination period. The study assessed the changes in seed storage protein content, storage protein profile, endopeptidase activity, free amino acids and gibberellic acid levels. Significant $(p<0.05)$ decrease in total storage protein after $24 \mathrm{hrs}$, albumin from $48 \mathrm{hrs}$ and globulin and glutelin after $72 \mathrm{hrs}$ germination period were observed in the studied landraces. Prolamin showed significant $(p<0.05)$ decrease after 48 hrs in all the landraces. Five peptide bands were detected in the six landraces with molecular weights corresponding to $97.4 \mathrm{kDa}, 45 \mathrm{kDa}, 29 \mathrm{kDa}, 20.1 \mathrm{kDa}$ and $18 \mathrm{kDa}$. Peptide bands with molecular weight of $97 \mathrm{kDa}$ and $29 \mathrm{kDa}$ decreased in intensity after $48 \mathrm{hrs}$ of germination in four landraces. Free amino acids content significantly $(p<0.05)$ increased following $24 \mathrm{hrs}$ germination period in all the landraces. The activity of endopeptidase increased significantly $(p<0.05)$, reaching maximum after $96 \mathrm{hrs}$ germination. Significant $(p<0.05)$ increase in gibberellic acid level throughout germination period was also observed. Although slow degradation rate of storage proteins was observed, there was variation in the rate at which storage protein and its fractions decreased among the bambaranut landraces during germination. This variation could be utilized towards obtaining improved bambaranut genotypes with better germination characteristics.
\end{abstract}

\section{Introduction}

Bambaranut (Vigna subteranea (L) Verdc.) is a drought tolerant legume known to have the ability to grow in soils with low fertility (1). The crop is widely cultivated using landraces of different seed colours. Only few studies have associated the seed coat colour with physiological and biochemical processes and the notable differences in seed quality among landraces (2). A number of issues including photoperiod and poor and slow germination are known to affect the production of bambaranut; these problems need to be solved in the near future to ensure its potentials towards global food, nutritional and environmental security are harnessed $(3,4)$.

Plants accumulate abundant reserves as carbohydrates, oils and proteins in their seeds during maturation which are crucial for seed germination and seedling establishment (5). Germination begins with imbibition of seeds with water and is concluded by the emergence of the radicle from the seed coat (6). Germination is accompanied by mobilization of food reserve from the storage organs (cotyledons or endosperm), providing essential energy to fuel growth until the seedlings become autotrophic (7). Seed storage protein mobilization during germination is among the vital events in the growth and development of seedlings (8). During germination, storage proteins are degraded by the action of endo and exopeptidases, proteolytic enzymes which convert the storage proteins into soluble peptides that are further hydrolyzed into free amino acids which are then mobilized to the embryonic axis to support growth (9).

Storage protein is the main reserve been frequently mobilized and used during germination of legume species (10). The relationship between seed reserves mobilization and germination has been reported in many economically-important species such as Oryza sativa (11) and Glycine max (12). The rate of degradation of storage proteins during germination is important in proper seedling establishment. For instance, fast rate of degradation of high molecular weight globulin polypeptides were reported during the early stages of germination of soybeans and faba beans (13).

Germination is a complex process affected by a number of integrating external (moisture, temperature, light and $\mathrm{pH}$ ) and internal (gibberellic acid (GA3), abscisic acid (ABA) and seed reserves) factors (14-17). The environmental factors affect germination through the regulation of biosynthesis

(c) Saminu \& Muhammad (2021). This is an open-access article distributed under the terms of the Creative Commons Attribution License, which permits unrestricted use, distribution and reproduction in any medium, provided the original author and source are credited (https://creativecommons.org/licenses/by/4.0/). 
and catabolism of GA3 and ABA respectively $(18,19)$. This study is aimed at determining the changes in seed storage protein mobilization in six bambaranut landraces during 96 hrs germination period.

\section{Materials and Methods}

\section{Sample collection}

Seeds of six landraces of bambaranut were locally obtained and identified in the Department of Plant Biology, Bayero University, Kano with a voucher number '0509'. The seeds were named Niger cream, Yobe cream, Yobe black, Kano mottled, Kano maroon and Kano brown based on their place of collection and colour. Eighty (80) seeds were randomly selected from each landrace and divided into four sets of 20 seeds; each set was then subjected to different germination period of 24, 48, 72 or $96 \mathrm{hrs}$.

\section{Germination procedure}

Germination was carried out according to standard procedure (20). Seeds were surface sterilized with $3.5 \%$ sodium hypochlorite solution for $5 \mathrm{~min}$ and then thoroughly rinsed with distilled water. The seeds were then soaked in $200 \mathrm{ml}$ distilled water for 6 hrs. The water imbibed seeds were germinated in petri dishes lined with water-soaked filter paper at room temperature. Germination was carried out in duplicate for each landrace and only $10 \mathrm{ml}$ distilled water was sprayed at a period of 5 hrs interval daily. Cotyledons from germinating seeds were collected at 24, 48, 72 and 96 hrs and frozen to stop the germination process. The seeds were then dried and crushed using a mortar and pestle, sieved and stored in air tight plastic containers. Water absorption capacity was determined from the weight of 100 seeds before and after imbibition. Radicle length was measured using a vernier caliper.

\section{Extraction and quantification of storage protein}

Seeds flour (10 gm) was defatted with n-hexane which was subsequently removed by decantation and leaving the flour to dry at room temperature. The extraction of total proteins was done as per standard method (21). Seed flour (1 gm) was dissolved in $10 \mathrm{ml}$ extraction buffer (50 mM phosphate buffer, $\mathrm{pH}$ 7.8), the homogenate was then vortexed and centrifuged at $10000 \mathrm{x} \mathrm{gm}$ for $10 \mathrm{~min}$ at $4{ }^{\circ} \mathrm{C}$. The supernatant was used for total protein estimation and sodium dodecyl sulphate polyacrylamide gel electrophoresis (SDSPAGE).

Storage protein fractions were sequential extracted based on their solubility (22). Seeds flour (1 gm) was dissolved in $10 \mathrm{ml}$ distilled water, the homogenate incubated for $30 \mathrm{~min}$ at $30{ }^{\circ} \mathrm{C}$ and subsequently centrifuged at $3000 \mathrm{x}$ g for $20 \mathrm{~min}$. The supernatant was recovered and pellet resuspended with $5 \mathrm{ml}$ distilled water, incubated for $30 \mathrm{~min}$ at 30 ${ }^{\circ} \mathrm{C}$ and centrifuged at $3000 \mathrm{x} \mathrm{g}$ for $20 \mathrm{~min}$. The supernatants were combined as albumin fraction. Globulin, glutelin and prolamin fractions were respectively extracted in a similar manner using $1 \%$ $\mathrm{NaCl}, 0.1 \mathrm{M} \mathrm{NaOH}$ and $70 \%$ ethanol as the solvents. Total protein was also quantified (23).

\section{Storage protein mobilization pattern}

SDS-PAGE analysis of total storage proteins of the 6 bambaranut landraces was carried out to determine peptides degradation pattern (24).

\section{Free amino acids determination}

Free amino acids were quantified (25). Seed flour (1 gm) was boiled with $10 \mathrm{ml} 80 \%$ ethanol for $10 \mathrm{~min}$. The homogenate was centrifuged at $3000 \mathrm{x}$ gm for 10 min, supernatant collected and pellet re-extracted twice; the supernatants were pooled together and filtered. The filtrate was used for the estimation of free amino acids by ninhydrin method using Ltyrosine as standard (26).

\section{Endopeptidase assay}

Crude endopeptidase extract was prepared (20). Seed flour (2 gm) was mixed with chilled $0.05 \mathrm{M}$ Tris- $\mathrm{HCl}$ buffer (pH 7.2), containing $2 \mathrm{mM} \beta$-mercaptoethanol $(1: 4 \mathrm{w} / \mathrm{v})$. The extract was filtered through four layers of cheesecloth and the filtrate centrifuged at $10000 \mathrm{x}$ gm for $15 \mathrm{~min}$ at $4{ }^{\circ} \mathrm{C}$. The supernatant was used for the enzyme assay. Endopeptidase activity was measured (27) using casein as substrate (25).

\section{Endogenous gibberellic acid determination}

Endogenous gibberellic acid (GA3) was extracted using $80 \%$ cold methanol at $4{ }^{\circ} \mathrm{C}$ (28). The concentration of endogenous GA3 was determined spectrophotometrically at $254 \mathrm{~nm}$ from a standard curve (29).

\section{Statistical analysis}

All data are presented as mean \pm standard deviation of three replicate analyses. For comparison, data were analyzed by ANOVA with Turkey's post-hoc test. All statistical analysis was based on a significance level of 0.05 . Analyses were done with SPSS software version 16.0 .

\section{Results and Discussion}

The dry weight of 100 seeds per landrace, water absorption capacity (WAC) and radicle length following 96 hrs germination period for the 6 bambaranut landraces are presented in Table 1. Kano brown had the highest weigh of 75 gm per 100 seeds and the least weight was found in Niger cream and Kano mottled landraces with 69 gm per 100 seeds. Yobe cream landrace had the highest WAC $(9.72 \%)$ following imbibition while Niger cream landrace had the least $(2.17 \%)$. Radicle emergence through seed coat was observed after 48 hrs in 4 of the landraces, after $72 \mathrm{hrs}$ in Kano maroon landrace and until 96 hrs in Niger cream landrace (Fig. 1). Significant $(p<0.05)$ increase in radicle length was observed across the various germination periods in all the landraces and the radicle lengths varied between the genotypes $(0.48-3.82 \mathrm{~cm})$ (Table 1$)$. Generally, landraces with higher WAC were the first to germinate (Fig. 1) and also possessed longer radicles.

Results indicated that the plain cream (Yobe cream) landrace has better germination indices compared to the other landraces. Previous studies 
Table 1. Seed weight, water absorption capacity and radical length during germination of bambaranut seeds.

\begin{tabular}{lrrrrrr}
\hline Parameters & \multicolumn{5}{c}{ bambaranut landrace } \\
\hline & Niger cream & Yobe cream & \multicolumn{1}{c}{ Yobe black } & Kano mottled & Kano maroon & Kano brown \\
\hline 100 Seeds Weight (g) & 69.00 & 72.00 & 70.00 & 69.00 & 70.00 & 75.00 \\
\hline WAC (\%) & 2.17 & 9.72 & 5.71 & 7.25 & 3.86 & 8.93 \\
\hline Radical length (cm) & & & & & & \\
\hline 24 hours & 0.00 & 0.00 & 0.00 & 0.00 & 0.00 & 0.00 \\
\hline 48 hours & 0.00 & $0.57^{\mathrm{a}} \pm 0.95$ & $0.34^{\mathrm{a}} \pm 0.13$ & $0.42^{\mathrm{a}} \pm 0.10$ & 0.00 & $0.85^{\mathrm{a}} \pm 0.20$ \\
\hline 72 hours & 0.00 & $2.54^{\mathrm{b}} \pm 0.32$ & $1.50^{\mathrm{b}} \pm 0.48$ & $1.58^{\mathrm{b}} \pm 0.44$ & $0.61^{\mathrm{a}} \pm 0.11$ & $1.97^{\mathrm{b}} \pm 0.34$ \\
\hline 96 hours & $0.48 \mathrm{~b} \pm 0.10$ & $3.82^{\mathrm{c}} \pm 0.39$ & $2.90^{\mathrm{c}} \pm 0.48$ & $2.96^{\mathrm{c}} \pm 0.46$ & $1.81^{\mathrm{b}} \pm 0.40$ & $3.16^{\mathrm{c}} \pm 0.30$ \\
\hline
\end{tabular}

Data expressed as mean \pm standard deviation, $\mathrm{n}=10$. Means with different superscript across columns are significantly different $(\mathrm{p}<0.05)$. $\mathrm{WAC}=$ water absorption capacity.

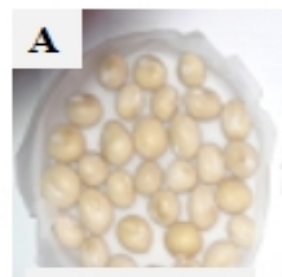

Yobe cream

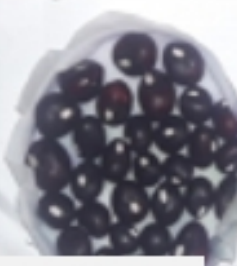

Yobe black

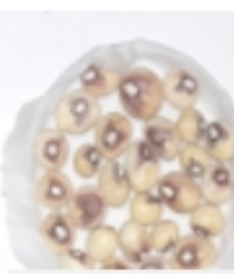

Niger cream

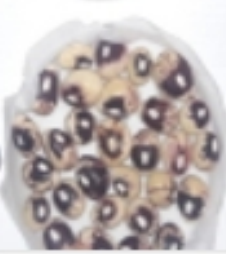

Kano mottled

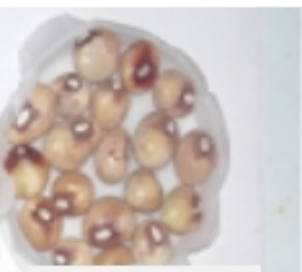

Kano brown

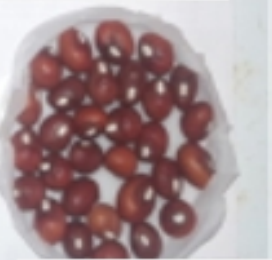

Kano maroon

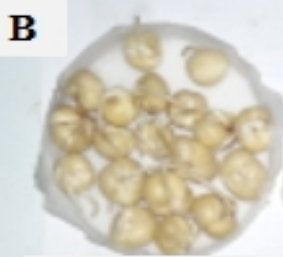

Yobe cream

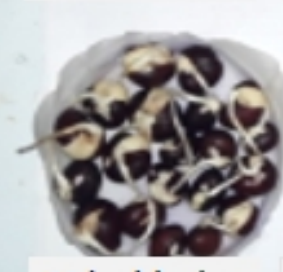

Yobe black

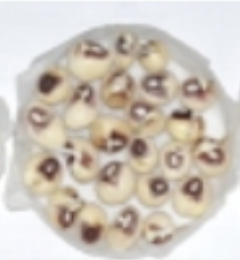

Niger cream

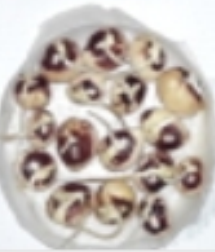

Kano mottled

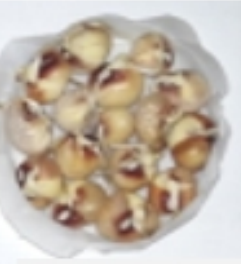

Kano brown

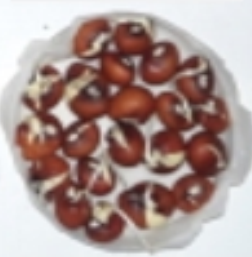

Kano maroon

Fig. 1. Bambaranut seeds showing radicle emergence during germination period.(A. seeds at $24 \mathrm{hrs}$, B. seeds at $96 \mathrm{hrs}$ germination periods).

$(30,31)$ on plain bambaranut indicated that darkcoloured seeds performed better compared to lightcoloured seeds. This was related to tannins, particularly polyphenols, present in dark-coloured seeds $(31,32)$. Polyphenols have antioxidant properties as such can confer a degree of stress tolerance during germination and seedling emergence. Since in the present study plain cream landrace performed better in term of water absorption, radicle emergence and length, it is suggested that water absorption capacity could be a useful selection criterion for seed quality in bambaranut towards solving the problem of poor and slow germination.

Sequential decrease in the concentration of total seed storage protein and protein fractions was generally observed in the bambaranut landraces during germination. With the exception of Niger cream landrace, significant $(p<0.05)$ decrease in total seed storage protein was observed in all the landraces by 48 hrs germination period with further decreases by 96 hrs (Table 2). Similar decreases were observed in the levels of albumins (Table 3) and globulins (Table 4). As presented in Table 5, the concentration of glutelins was only observed to decrease significantly $(p<0.05)$ after 72 to 96 hrs germination period while the level of prolamins was significantly $(\mathrm{p}<0.05)$ decreased by $48 \mathrm{hrs}$ and subsequently continued to decrease but insignificantly (Table 6). In all the landraces of bambaranut, differences were observed in the pattern of decrease in seed storage protein and its fraction.
The storage proteins are important because they determine both the quantity and quality of seed proteins for various uses in metabolism (33). The concentration of total seed storage proteins and its fractions of the 6 bambaranut landraces decreased significantly $(p<0.05)$ upon germination for $96 \mathrm{hrs}$. The decrease in storage protein concentration could be attributed to the degradation of storage proteins by proteases (25). Water imbibition and germination lead to several physiological and metabolic changes in plant seeds as all the nutrients and energy necessary for the growth and development of the embryonic axis are derived from storage compounds within the seeds (34). Slow depletion of seed storage proteins at the initial stages (24 to $48 \mathrm{hrs}$ ) of germination followed by gradual increase in depletion of protein content was observed in many legume species: Indian bean (35), broad bean (36) and horse gram seeds (37). Thus, the degradation of major storage protein can be considered to be species dependent (38).

Fig. 2 presents the SDS-PAGE electrophoregram of storage protein of bambaranut seeds during $96 \mathrm{hrs}$ germination period. There was no observed difference in the peptide bands pattern of Niger cream (L1-L4) and Yobe cream (L5-L8) landraces throughout the germination period. From 48 to $96 \mathrm{hrs}$ germination period there was an observable decrease in intensity of $97.4 \mathrm{kDa}$ molecular weight peptide bands in Kano brown landrace (L21-L24). Throughout the studied germination period, in all the landraces, the intensity of a $45 \mathrm{kDa}$ peptide band remained relatively unchanged. Decrease in intensity 
Table 2. Total seed storage protein concentration during germination of bambaranut.

\begin{tabular}{ccccccc}
\hline $\begin{array}{l}\text { Germination } \\
\text { time (hours) }\end{array}$ & \multicolumn{5}{c}{ Total seed storage protein (mg/ml) } \\
\cline { 2 - 7 } & Niger cream & Yobe cream & Yobe black & Kano mottled & Kano maroon & Kano brown \\
\hline 24 & $0.087^{\mathrm{a}} \pm 0.002$ & $0.100^{\mathrm{a}} \pm 0.002$ & $0.099^{\mathrm{a}} \pm 0.001$ & $0.082^{\mathrm{a}} \pm 0.001$ & $0.082^{\mathrm{a}} \pm 0.001$ & $0.118^{\mathrm{a}} \pm 0.003$ \\
\hline 48 & $0.082^{\mathrm{a}} \pm 0.003$ & $0.084^{\mathrm{b}} \pm 0.002$ & $0.088^{\mathrm{b}} \pm 0.003$ & $0.074^{\mathrm{b}} \pm 0.000$ & $0.078^{\mathrm{b}} \pm 0.001$ & $0.111^{\mathrm{b}} \pm 0.000$ \\
\hline 72 & $0.076^{\mathrm{b}} \pm 0.003$ & $0.065^{\mathrm{c}} \pm 0.001$ & $0.073^{\mathrm{c}} \pm 0.000$ & $0.072^{\mathrm{b}} \pm 0.002$ & $0.073^{\mathrm{b}} \pm 0.002$ & $0.096^{\mathrm{c}} \pm 0.001$ \\
\hline 96 & $0.065^{\mathrm{c}} \pm 0.002$ & $0.058^{\mathrm{d}} \pm 0.003$ & $0.060^{\mathrm{d}} \pm 0.002$ & $0.062^{\mathrm{c}} \pm 0.003$ & $0.068^{\mathrm{c}} \pm 0.000$ & $0.083^{\mathrm{d}} \pm 0.003$ \\
\hline
\end{tabular}

Data are expressed as mean \pm standard deviation of triplicate measurements. Means with different superscript across a column are significantly different $(\mathrm{p}<0.05)$.

Table 3. Albumin fraction concentration during germination of bambaranut.

\begin{tabular}{|c|c|c|c|c|c|c|}
\hline \multirow{2}{*}{$\begin{array}{c}\text { Germination time } \\
\text { (hours) }\end{array}$} & \multicolumn{6}{|c|}{ Albumin fraction (mg/ml) } \\
\hline & Niger cream & Yobe cream & Yobe black & Kano mottled & Kano maroon & Kano brown \\
\hline 24 & $0.019^{\mathrm{a}} \pm 0.001$ & $0.026^{\mathrm{a}} \pm 0.002$ & $0.034^{\mathrm{a}} \pm 0.001$ & $0.022^{\mathrm{a}} \pm 0.004$ & $0.026^{\mathrm{a}} \pm 0.001$ & $0.023^{\mathrm{a}} \pm 0.002$ \\
\hline 48 & $0.018^{a} \pm 0.000$ & $0.018^{\mathrm{b}} \pm 0.002$ & $0.029^{b} \pm 0.001$ & $0.022^{\mathrm{a}} \pm 0.000$ & $0.022^{\mathrm{a}} \pm 0.001$ & $0.022^{\mathrm{a}} \pm 0.000$ \\
\hline 72 & $0.009^{b} \pm 0.001$ & $0.012^{\mathrm{b}} \pm 0.002$ & $0.023^{\mathrm{c}} \pm 0.000$ & $0.021^{\mathrm{a}} \pm 0.003$ & $0.018^{\mathrm{b}} \pm 0.001$ & $0.018^{\mathrm{b}} \pm 0.002$ \\
\hline 96 & $0.005^{\mathrm{b}} \pm 0.002$ & $0.005^{c} \pm 0.003$ & $0.021^{\mathrm{c}} \pm 0.002$ & $0.014^{\mathrm{b}} \pm 0.002$ & $0.018^{\mathrm{b}} \pm 0.000$ & $0.017^{\mathrm{b}} \pm 0.000$ \\
\hline
\end{tabular}

Data are expressed as mean \pm standard deviation of triplicate measurements. Means with different superscript across column are significantly different $(\mathrm{p}<0.05)$.

Table 4. Globulin fraction concentration during germination of bambaranut. Germination time (hours)

\begin{tabular}{ccccccc}
\hline & Niger cream & Yobe cream & Yobe black & Kano mottled & Kano maroon & Kano brown \\
\hline 24 & $0.057^{\mathrm{a}} \pm 0.002$ & $0.063^{\mathrm{a}} \pm 0.001$ & $0.056^{\mathrm{a}} \pm 0.000$ & $0.046^{\mathrm{a}} \pm 0.001$ & $0.043^{\mathrm{a}} \pm 0.002$ & $0.085^{\mathrm{a}} \pm 0.002$ \\
\hline 48 & $0.054^{\mathrm{a}} \pm 0.003$ & $0.058^{\mathrm{b}} \pm 0.001$ & $0.051^{\mathrm{a}} \pm 0.000$ & $0.041^{\mathrm{b}} \pm 0.002$ & $0.039^{\mathrm{b}} \pm 0.000$ & $0.081^{\mathrm{b}} \pm 0.000$ \\
\hline 72 & $0.050^{\mathrm{b}} \pm 0.001$ & $0.056^{\mathrm{b}} \pm 0.000$ & $0.046^{\mathrm{b}} \pm 0.001$ & $0.038^{\mathrm{c}} \pm 0.001$ & $0.032^{\mathrm{c}} \pm 0.001$ & $0.073^{\mathrm{c}} \pm 0.002$ \\
\hline 96 & $0.046^{\mathrm{b}} \pm 0.001$ & $0.049^{\mathrm{c}} \pm 0.000$ & $0.040^{\mathrm{b}} \pm 0.001$ & $0.034^{\mathrm{c}} \pm 0.001$ & $0.023^{\mathrm{d}} \pm 0.003$ & $0.070^{\mathrm{c}} \pm 0.001$ \\
\hline
\end{tabular}

Table 5. Glutelin fraction concentration during germination of bambaranut. Germination time (hours)

\begin{tabular}{crrrrrr}
\hline & \multicolumn{1}{c}{ Niger cream } & \multicolumn{1}{c}{ Yobe cream } & \multicolumn{1}{c}{ Yobe black } & \multicolumn{1}{c}{ Kano mottled } & Kano maroon & \multicolumn{1}{c}{ Kano brown } \\
\hline 24 & $0.006^{\mathrm{a}} \pm 0.003$ & $0.007^{\mathrm{a}} \pm 0.001$ & $0.013^{\mathrm{a}} \pm 0.001$ & $0.009^{\mathrm{a}} \pm 0.002$ & $0.007^{\mathrm{a}} \pm 0.001$ & $0.007^{\mathrm{a}} \pm 0.001$ \\
\hline 48 & $0.005^{\mathrm{a}} \pm 0.001$ & $0.006^{\mathrm{a}} \pm 0.000$ & $0.012^{\mathrm{a}} \pm 0.001$ & $0.007^{\mathrm{a}} \pm 0.002$ & $0.006^{\mathrm{a}} \pm 0.000$ & $0.004^{\mathrm{b}} \pm 0.000$ \\
\hline 72 & $0.003^{\mathrm{b}} \pm 0.001$ & $0.004^{\mathrm{b}} \pm 0.000$ & $0.012^{\mathrm{a}} \pm 0.000$ & $0.004^{\mathrm{b}} \pm 0.000$ & $0.005^{\mathrm{a}} \pm 0.001$ & $0.003^{\mathrm{b}} \pm 0.001$ \\
\hline 96 & $0.002^{\mathrm{b}} \pm 0.000$ & $0.003^{\mathrm{b}} \pm 0.001$ & $0.009^{\mathrm{a}} \pm 0.002$ & $0.004^{\mathrm{b}} \pm 0.000$ & $0.004^{\mathrm{a}} \pm 0.000$ & $0.001^{\mathrm{c}} \pm 0.000$ \\
\hline
\end{tabular}

Table 6. Prolamin fraction concentration during germination of bambaranut.

\begin{tabular}{crrrrrr}
$\begin{array}{c}\text { Germination } \\
\text { time (hours) }\end{array}$ & \multicolumn{5}{c}{ Prolamin fraction (mg/ml) } \\
\hline & Niger cream & Yobe cream & Yobe black & \multicolumn{1}{c}{ Kano mottled } & Kano maroon & Kano brown \\
\hline 24 & $0.002^{\mathrm{a}} \pm 0.000$ & $0.003^{\mathrm{a}} \pm 0.001$ & $0.002^{\mathrm{a}} \pm 0.000$ & $0.003^{\mathrm{a}} \pm 0.000$ & $0.002^{\mathrm{a}} \pm 0.001$ & $0.0023^{\mathrm{a}} \pm 0.001$ \\
\hline 48 & $0.001^{\mathrm{b}} \pm 0.000$ & $0.003^{\mathrm{a}} \pm 0.001$ & $0.002^{\mathrm{a}} \pm 0.000$ & $0.002^{\mathrm{b}} \pm 0.001$ & $0.002^{\mathrm{a}} \pm 0.001$ & $0.002^{\mathrm{b}} \pm 0.000$ \\
\hline 72 & $0.001^{\mathrm{b}} \pm 0.000$ & $0.002^{\mathrm{c}} \pm 0.000$ & $0.001^{\mathrm{b}} \pm 0.000$ & $0.002^{\mathrm{b}} \pm 0.000$ & $0.001^{\mathrm{b}} \pm 0.001$ & $0.002^{\mathrm{b}} \pm 0.0001$ \\
\hline 96 & $0.001^{\mathrm{b}} \pm 0.000$ & $0.002^{\mathrm{c}} \pm 0.001$ & $0.001^{\mathrm{b}} \pm 0.002$ & $0.001^{\mathrm{c}} \pm 0.001$ & $0.001^{\mathrm{b}} \pm 0.000$ & $0.002^{\mathrm{b}} \pm 0.0001$ \\
\hline
\end{tabular}

Data are expressed as mean \pm standard deviation of triplicate measurements. Means with different superscript across column are significantly different $(\mathrm{p}<0.05)$.

of $29 \mathrm{kDa}$ and $20.1 \mathrm{kDa}$ bands was observed by $48 \mathrm{hrs}$ with a prominent decrease by $96 \mathrm{hrs}$ germination period in four of the bambaranut landraces.

Gradual disappearance of $29 \mathrm{kDa}$ band in L11 and L12 (Yobe black), L15 and L16 (Kano mottle), L19 and L20 (Kano maroon), and L23 and 24 (Kano brown) was observed. In the other two landraces (Niger cream and Yobe cream), no notable decrease in intensity nor gradual disappearance of peptide bands was observed. The differences seen in the pattern of degradation of the peptides could be an indication of genetic variability among the studied landraces. SDS-PAGE has been widely used for monitoring protein mobilization at the early stages of seed germination (39). It was reported that major storage protein (vicilin-type globulins) follow distinct degradation patterns during germination in different plant species (38). The morphological and phenotypic differences in the seeds of bambaranut landraces are pointers of genetic difference. Even though there were similarities among the studied landraces, differences in number of peptides, degradation pattern and evident preferential degradation of some peptides over others during the germination were observed.

The free amino acids content of the 6 bambaranut landraces during $96 \mathrm{hrs}$ of germination are presented in Table 7. Significant $(p<0.05)$ increase in free amino acids concentration was seen throughout the germination period; observable differences were also evident between the landraces. Following seed imbibition and germination, storage proteins enlarge as a consequence of increase in osmotic potential due to proteolysis which releases free amino acids $(25,40)$. Studies have reported increase in free amino acids content during germination in legumes species such as horse gram, Indian bean and broad bean $(25,35,36)$. The activities of proteolytic enzymes lead to the 


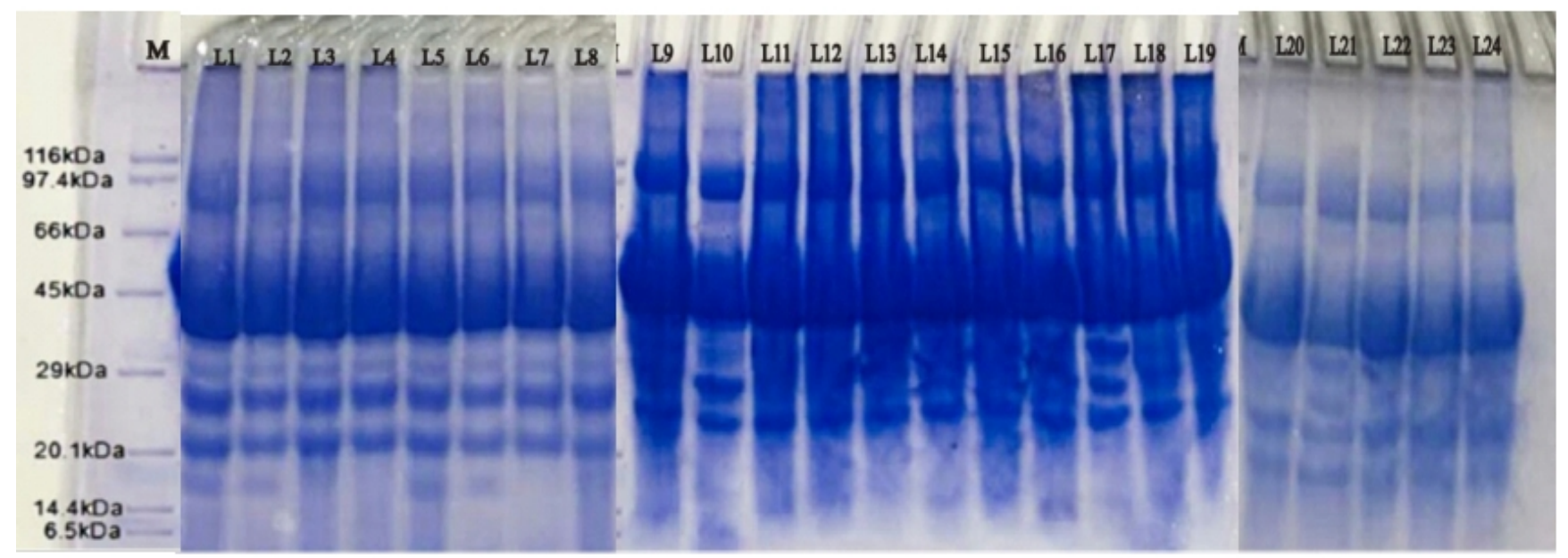

Fig. 2. SDS-PAGE electrophoregram of seed storage proteins of six bambaranut landraces from 24 to 96 hours germination period. Lanes: M = molecular weight marker; L1-L4 = Niger cream; L5-L8 = Yobe cream; L9-L12 = Yobe black; L13-L16 = Kano mottled; L17-L20 = Kano maroon; L21-L24 = Kano brown following 24, 48, 72 and 96 hrs germination periods respectively.

Table 7. Free amino acids concentration during germination of bambaranut seeds.

\begin{tabular}{crrrrrr}
\hline $\begin{array}{c}\text { Germination } \\
\text { time (hours) }\end{array}$ & \multicolumn{5}{c}{ Free amino acid $(\mu \mathrm{\mu g} / \mathbf{m l})$} \\
\cline { 2 - 7 } & \multicolumn{1}{c}{ Niger cream } & Yobe cream & Yobe black & \multicolumn{1}{c}{ Kano mottled } & Kano maroon & \multicolumn{1}{c}{ Kano brown } \\
\hline 24 & $102.72^{\mathrm{a}} \pm 0.35$ & $118.93^{\mathrm{a}} \pm 0.35$ & $113.41^{\mathrm{a}} \pm 0.00$ & $106.61^{\mathrm{a}} \pm 1.05$ & $105.37^{\mathrm{a}} \pm 2.24$ & $171.69^{\mathrm{a}} \pm 2.26$ \\
\hline 48 & $180.43^{\mathrm{b}} \pm 0.20$ & $207.21^{\mathrm{b}} \pm 0.59$ & $189.04^{\mathrm{b}} \pm 0.41$ & $192.61^{\mathrm{b}} \pm 0.53$ & $176.06^{\mathrm{b}} \pm 1.39$ & $247.21^{\mathrm{b}} \pm 2.16$ \\
\hline 72 & $197.63^{\mathrm{c}} \pm 2.04$ & $251.80^{\mathrm{c}} \pm 0.40$ & $246.52^{\mathrm{c}} \pm 0.90$ & $242.04^{\mathrm{c}} \pm 0.91$ & $192.72^{\mathrm{c}} \pm 1.80$ & $293.87^{\mathrm{c}} \pm 3.09$ \\
\hline 96 & $257.90^{\mathrm{d}} \pm 0.69$ & $330.31^{\mathrm{d}} \pm 0.59$ & $286.17^{\mathrm{d}} \pm 2.00$ & $267.32^{\mathrm{d}} \pm 1.38$ & $246.97^{\mathrm{d}} \pm 2.41$ & $363.07^{\mathrm{d}} \pm 1.58$ \\
\hline
\end{tabular}

Data are expressed as mean \pm standard deviation of triplicate measurements. Means with different superscript across columns differ significantly $(\mathrm{p}<0.05)$.

significant increase in free amino acids content during germination $(41,42)$.

In the present study, endopeptidase activity increased significantly $(\mathrm{p}<0.05)$ during the $96 \mathrm{hrs}$ germination period (Table 8). It reached maximum activity at $72 \mathrm{hrs}$ of germination and declined by 96 hrs in four of the 6 bambaranut landraces; however, the activity continued to rise in the other two landraces up to $96 \mathrm{hrs}$ germination period. Furthermore, the endopeptidase activity was observed to be positively related to the free amino acid level. It was stated that free amino acid contents increase during germination due to resultant activities of proteolytic enzymes (42).

The positive correlation between endoprotease activity and protein depletion suggests the involvement of endoprotease in the degradation of proteins or peptides to free amino acids in the cotyledons of germinating seeds (25). Changes in endopeptidase activity, free amino acid and protein concentration have been reported by previous studies in legumes such as horse gram, Indian bean, soybean and broad bean $(25,35,41,43)$.

Significant $(\mathrm{p}<0.05)$ increase in the concentration of GA3 was observed by $48 \mathrm{hrs}$ germination period and it continued to rise throughout the germination period (Table 9). Longitudinal growth and water uptake in the root and shoot within the growing axis are enhanced by endogenous gibberellin (44). GA3 stimulates storage protein mobilization by inducing synthesis of hydrolytic enzymes (19). Application of exogenous GA3 was reported to increase seed weight and delayed seed dehydration, suggesting the role of GA3 during seed germination and in later stages of seedlings development (45).

In the present study, WAC during seeds imbibition can be considered as a more important parameter in breaking the physical dormancy caused by the hard seed coat of bambaranut. Therefore, WAC can be considered to have more effect than storage protein degradation and GA3 at the early stages of germination (radicle emergence) before the onset active cell division and enlargement as well as proper root and shoot development. It was reported that endogenous GA3 is closely related to cell division and cell enlargement (46).

Endogenous GA3 content was reported to have effect on endopeptidase activity indicating its influence on protein degradation (47). Earlier studies have reported the influence of gibberellins on seed germination and protein mobilization by affecting endopeptidase activity (47, 48). Therefore endogenous GA3 might have its effect more pronounced at the late germination stages of bambaranut when proper roots and shoots were developed or during the onset of its seedlings establishment.

In the present study it was observed that landraces with dark coloured seed coat (black, mottle, maroon and brown) showed sign of faster protein degradation rate. Similarly, landraces with dark coloured seed coats had higher levels of 
Table 8. Endopeptidase activity expressed as microgrammes of free amino acids released/hour/ml in germinating bambaranut seeds.

\begin{tabular}{ccccrrr}
\hline $\begin{array}{l}\text { Germination } \\
\text { time (hours) }\end{array}$ & \multicolumn{5}{c}{ Endopeptidase activity $\boldsymbol{\mu g} / \mathbf{h o u r} / \mathbf{m l}$} \\
\hline & Niger cream & Yobe cream & \multicolumn{1}{c}{ Yobe black } & Kano mottled & \multicolumn{1}{c}{ Kano maroon } & Kano brown \\
\hline 24 & $24.22^{\mathrm{a}} \pm 0.52$ & $31.46^{\mathrm{a}} \pm 0.40$ & $52.03^{\mathrm{a}} \pm 0.60$ & $29.50^{\mathrm{a}} \pm 1.40$ & $43.76^{\mathrm{a}} \pm 2.15$ & $27.44^{\mathrm{a}} \pm 2.08$ \\
\hline 48 & $42.03^{\mathrm{b}} \pm 1.19$ & $74.22^{\mathrm{b}} \pm 1.40$ & $82.84^{\mathrm{b}} \pm 0.40$ & $51.00^{\mathrm{b}} \pm 1.38$ & $78.93^{\mathrm{b}} \pm 0.00$ & $78.93^{\mathrm{b}} \pm 0.00$ \\
\hline 72 & $64.33^{\mathrm{c}} \pm 1.05$ & $113.89^{\mathrm{c}} \pm 0.56$ & $114.79^{\mathrm{c}} \pm 0.35$ & $73.07^{\mathrm{c}} \pm 1.92$ & $116.07^{\mathrm{c}} \pm 1.41$ & $115.70^{\mathrm{a}} \pm 2.96$ \\
\hline 96 & $62.38^{\mathrm{c}} \pm 0.59$ & $109.51^{\mathrm{c}} \pm 0.40$ & $129.39^{\mathrm{d}} \pm 0.40$ & $68.41^{\mathrm{d}} \pm 1.82$ & $122.15^{\mathrm{d}} \pm 1.55$ & $105.83^{\mathrm{d}} \pm 2.82$ \\
\hline Data are expressed as mean \pm standard deviation of triplicate measurements. Means with different superscript across columns differ
\end{tabular}
significantly $(\mathrm{p}<0.05)$.

Table 9. Gibberellic acid concentration during germination of bambaranut.

\begin{tabular}{cccccrr}
\hline $\begin{array}{c}\text { Germination time } \\
\text { (Hours) }\end{array}$ & \multicolumn{5}{c}{ Endogenous gibberellic acid (mg/ml) } \\
\hline & Niger cream & Yobe cream & Yobe black & Kano mottled & Kano maroon & Kano brown \\
\hline 24 & $0.05^{\mathrm{a}} \pm 0.00$ & $0.07^{\mathrm{a}} \pm 0.01$ & $0.11^{\mathrm{a}} \pm 0.00$ & $0.06^{\mathrm{a}} \pm 0.02$ & $0.09^{\mathrm{a}} \pm 0.00$ & $0.10^{\mathrm{a}} \pm 0.01$ \\
\hline 48 & $0.07^{\mathrm{b}} \pm 0.00$ & $0.10^{\mathrm{b}} \pm 0.00$ & $0.15^{\mathrm{b}} \pm 0.01$ & $0.08^{\mathrm{a}} \pm 0.00$ & $0.14^{\mathrm{b}} \pm 0.01$ & $0.12^{\mathrm{b}} \pm 0.00$ \\
\hline 72 & $0.08^{\mathrm{b}} \pm 0.01$ & $0.12^{\mathrm{c}} \pm 0.01$ & $0.17^{\mathrm{b}} \pm 0.00$ & $0.13^{\mathrm{b}} \pm 0.00$ & $0.16^{\mathrm{b}} \pm 0.01$ & $0.16^{\mathrm{c}} \pm 0.00$ \\
\hline 96 & $0.14^{\mathrm{c}} \pm 0.01$ & $0.17^{\mathrm{d}} \pm 0.01$ & $0.26^{\mathrm{c}} \pm 0.01$ & $0.20^{\mathrm{c}} \pm 0.01$ & $0.21^{\mathrm{c}} \pm 0.00$ & $0.22^{\mathrm{d}} \pm 0.01$ \\
\hline
\end{tabular}

Data are expressed as mean \pm standard deviation of triplicate measurements. Means with different superscript across columns are significantly different $(\mathrm{p}<0.05)$.

endopeptidase activity and GA3. Previous studies have reported that dark coloured bambaranut seeds performed better compared to light coloured seeds during germination and seedlings establishment which might be due to faster rate of protein degradation in addition to high content of polyphenols $(30,31)$.

The germination potential of a plant species is governed by a number of factors including environmental and genetic makeup. The observed variability among the bambaranut genotypes studied is a pointer of their potential towards breeding varieties with better germination rates and success.

\section{Conclusion}

The effect of germination on the assessed biochemical parameters indicates the existence of varied mechanism approach in storage protein degradation and mobilization during germination among the studied bambaranut landraces. Variation was observed in the pattern of storage protein, endopeptidase activities, free amino acid and endogenous GA3 contents. Among the studied bambaranut genotypes, two landraces Yobe cream and Kano brown indicated better germination ability, although neither of the two landraces has the highest GA3 level. The variability in storage protein mobilization and germination of bambaranut landraces could be exploited towards improvement of local genotypes to obtain accessions with better agronomic properties, including germination rate and success.

\section{Acknowledgements}

The authors wish to acknowledge Dr. Idi Aminu and Aminu Baba, both of the Department of Biochemistry, Bayero University, for their immense contributions during the laboratory work. The authors also thank Bayero University, Kano for providing the laboratory facilities for the work.

\section{Authors' contributions}

NMS carried out the laboratory and statistical analyses and prepared the draft manuscript. YYM conceived the study and participated in its design and coordination. All authors read and approved the final manuscript.

\section{Conflict of interests}

Authors do not have any conflict of interests to declare.

\section{References}

1. Linnemann AR, Azam-Ali SN. Bambara groundnut (Vigna subterranea (L.) Verdc.). In: Underutilised Crop Series I. Vegetables and Pulses. Chapman and Hall, London, UK; 1993.

2. Mandizvo T, Odindo AO. Seed coat structural and imbibitional characteristics of dark and light coloured Bambara groundnut (Vigna subterranea (L) Verdc.) landraces. Heliyon 2019;5:e01249. https://doi.org/10.1016/j.heliyon.2019.e01249

3. Kendabie P, Jørgensen ST, Massawe F, Fernandez J, AzamAli S, Mayes S. Photoperiod control of yield and sink capacity in Bambara groundnut (Vigna subterranea) genotypes. Food and Energy Secur. 2020;9(4):1-16 https://doi.org/10.1002/fes3.240

4. Massawe FJ, Azam-Ali NS, Roberts JA. The impact of temperature on seed germination in Bambara groundnut (Vigna subterranea (L.) Verdc.) landraces. Seed Sci. Tech. 2003;31(2):259-73. https://doi.org/10.15258/sst.2003.31.2.04

5. Weber H, Borisjuk L, Wobus U. Molecular physiology of legumes seed development. Ann Rev Plant Biol. 2005;56:253-79. https://doi.org/10.1146/annurev.arplant.56.032604.144201

6. Rajjou L, Duval M, Gallardo K, Catusse J, Bally J, Job C, Job D. Seed germination and vigor. Ann Rev Plant Biol. 2012;63:507-33. https://doi.org/10.1146/annurev-arplant042811-105550

7. Bewley JD. Seed germination and dormancy. Plant Cell 1997;9(7):1055-66. https://doi.org/10.1105/tpc.9.7.1055

8. Muntz K, Belozersky MA, Dunaevsky YE, Schlereth A, Tiedemann J. Stored proteinases and the initiation of storage protein mobilization in seeds during germination 
and seedling growth. J Exp Bot. 2001;52(362):1741-52. https://doi.org/10.1093/jexbot/52.362.1741

9. Schlereth A, Standhardt D, Mock HP, Muntz K. Stored cysteine proteanase start globulin breakdown in protein bodies of embryonic axis and cotyledons of germinating vetch (Vicia sativa L.) seeds. Planta 2001;212:718-27. https:// doi.org/10.1007/s004250000436

10. Zhoa M, Zhang H, Yan H, Qiu L, Baskin CC. Mobilization and role of starch, protein and fat reserves during seed germination of six wild grassland species. Front Plant Sci. 2018;9:1-11 https://doi.org/10.3389/fpls.2018.00234

11. Sun J, Wu $\mathrm{D}, \mathrm{Xu}$ J. Characterization of starch during germination and seedling development of a rice mutant with a content of resistant starch. J Cereal Sci. 2015;62:94101. https://doi.org/10.1016/j.jcs.2015.01.002

12. Bellaloui N, Smith JR, Mengistu A, Ray JD, Gillen AM. Evaluation of exotically-derived soybean breeding lines for seed yield, germination, damage and composition under dryland production in the mid-southern USA. Front. Plant Sci. 2017;8:1-20. https://doi.org/10.3389/fpls.2017.00176

13. Savelkoul F, Boer H, Tamminga S, Schepers AJ, Elburg L. In vitro enzymatic hydrolysis of protein and protein pattern change of soya and faba beans during germination. Plant Foods Hum Nutr. 1992;42:275-84. https://doi.org/10.1007/BF02193935

14. Ramakrishna V. Mobilization of albumins and globulins during germination of Indian bean (Dolichos lablab L. var. lignosus) seeds. Acta Bot Croat. 2007;66(2):135-42.

15. Han C, Yin X, He D, Yang P. Analysis of proteome profile in germinating soybean seeds and its comparison with rice showing the styles of reserves mobilization in different crops. PLoS ONE 2007;8(2):e56947. https://doi.org/10.1371/journal.pone.0056947

16. Penfield S, Josse EM, Kannangara R, Gilday AD, Halliday KE. Cold and light control seed germination through the bHLH transcription factor SPATULA. Curr Biol. 2005;15(22):19982006. https://doi.org/10.1016/j.cub.2005.11.010

17. Chen H, Zhang J, Neff MM, Hong SW, Zhang H. Integration of light and ABA signalling during seed germination and early seedling development. Proc Nat Acad Sci. 2008; 105(11):4495-4500. https://doi.org/10.1073/pnas.0710778105

18. Finch-Savage WE, Leubner-Metzger G. Seed dormancy and the control of germination. New Phytol. 2006;171(3):501-23. https://doi.org/10.1111/j.1469-8137.2006.01787.x

19. Pawlowski TA. Proteomics of European beech (Fagus sylvatica L.) seed dormancy breaking: Influence of abscisic and gibberellic acids. Proteomics 2007;7(13):2246-57. https://doi.org/10.1002/pmic.200600912

20. Jinka R, Ramakrishna V, Rao SK, Roa PR. Purification and characterization of cysteine proteases from germinating cotyledons of horse gram. BMC Biochem. 2009;10:28. https://doi.org/10.1186/1471-2091-10-28

21. Hameed A, Shah, TM, Atta BM, Iqbal N, Haq MA, Ali H. Comparative seed storage protein profiling of kabuli genotypes. Pakistani J Bot. 2009;41(2):703-10.

22. Silva, S., Francisco, F. and Dantas, F. Quantification of storage proteins during seed imbibitions of native species from the Brazillian catinga vegetation. Semina: Ciencias Agrarias 2016; 37(4):1733-44. https://doi.org/10.5433/1679$0359.2016 \mathrm{v} 37 \mathrm{n} 4 \mathrm{p} 1733$

23. Bradford MM. A rapid and sensitive method for the quantitation of microgram quantities of protein utilizing the principle of protein-dye binding. Anal Biochem. 1976; 72(1):248-54. https://doi.org/10.1016/0003-2697(76)90527-3

24. Laemmli UK. Cleavage of structural proteins during assembly of the head of bacteriophage T4. Nature 1970;227:680-85. https://doi.org/10.1038/227680a0

25. Jinka R, Roa PR. Storage protein degradation in germinating horse gram seed. Indian J. Plant Physiol. 2002;7(4):314-20.

26. Raghuramulu N, Madhavan NK, Kalyanasundaram S. A manual of laboratory techniques. National Institute of Nutrition, Hydrabad India. 2003.
27. Beevers L. Protein degradation and proteolytic activity in the cotyledons of germinating pea (Pisum sativum) seeds. Phytochem. https://doi.org/10.1016/S0031-9422(00)86656-X

28. Badr SA, Martin GC, Hartmann HT. A modified method for extraction and identification of abscisic acid and gibberellin-like substances from the Olive (Olea europaea). Physiol Plant. 1971;24(2):191-98. https://doi.org/10.1111/j.1399-3054.1971.tb03477.x

29. Berrios J, Illanes A, Aroca G. Spectrophotometric method for determining gibberellic acid in fermentation broths. Biotechnol Lett. 2004;26:67-70. https://doi.org/10.1023/B:BILE.0000009463.98203.8b

30. Sinefu F. Bambara groundnut response to controlled environment and planting date associated water stress. MSc [thesis]. University of KwaZulu-Natal, Pietermaritzburg, South Africa; 2011.

31. Mabhaudhi T, Modi AT, Beletse YG. Growth, phenological and yield responses of a Bambara groundnut (Vigna subterranea L. Verdc) landrace to imposed water stress: II. Rain shelter conditions. Water SA 2013;39(2):191-98. https:// doi.org/10.4314/wsa.v39i2.2

32. Michalak A. Phenolic compounds and their anti-oxidant activity in plants growing under heavy metal stress. Pol J Environ Stud. 2006;4:523-30.

33. Alwhibi, M. S. Characterization of seed storage protein patterns of Heliotropium digynum. Saudi J Biol Sci. 2017;24(6):1404-09. https://doi.org/10.1016/j.sjbs.2016.08.008

34. Bewley JD, Black M. Seeds: Physiology of development and germination. 2nd edition Plenum Press, New York, London; 1994. https://doi.org/10.1007/978-1-4899-1002-8

35. Ramakrishna V, Rao PR. Storage protein degradation in germinating Indian bean (Dolichos lablab L. var. lignosus) seeds. Seed Sci Technol. 2006;34(1):161-68. https://doi.org/10.15258/sst.2006.34.1.17

36. Kirmizi S, Guleryuz G. Monitoring protein mobilization during seed germination of broad bean (Vicia faba L.)

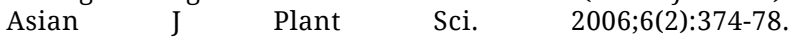
https://doi.org/10.3923/ajps.2007.374.378

37. Pang PG, Asrul A, Rahman S, Shaha RK. Sodium dodecyl sulphate polyacrylamide gel electrophoresis pattern of horse gram seed storage proteins during germination. Int. Research J Biol Sci. 2012;1(4):39-50.

38. Freitas RL, Teixeira AR,Ferreira RB. Vicilin-type globulins follow distinct patterns of degradation in different species of germinating legume seeds. Food Chem. 2007;102(1):32329. https://doi.org/10.1016/j.foodchem.2006.05.023

39. Krochko JE, Bewley JD. Seed storage proteins in cultivars and subspecies of alfalfa (Medicago sativa L.). Seed Sci Res. 2000;10(4):423-34.

https://doi.org/10.1017/S0960258500000477

40. Wrobel R, Jones BL. Appearance of endoproteolytic enzymes during the germination of barley. Plant Physiol. 1992;100(3):1508-16. https://doi.org/10.1104/pp.100.3.1508

41. Kirmizi S, Guleryuz G. Protein mobilization and proteolytic enzyme activities during seed germination of broad bean (Vicia faba L.). Z. Naturforsch. C. 2006;61(3):222-26. https://doi.org/10.1515/znc-2006-3-411

42. Muntz K. Proteases and proteolytic cleavage of storage proteins in developing and germinating dicotyledons seeds. J Exp Bot. 1996;47(5):605-22. https://doi.org/10.1093/jxb/47.5.605

43. Qi X, Wilson KA, Tan-Wilson AL. Characterization of the major protease involved in the soybean $\beta$-conglycinin storage protein mobilization. Plant Physiol. 1992;99(2):72533. https://doi.org/10.1104/pp.99.2.725

44. Banyal S, Rai VK. Reversal of osmotic stress effect by gibberellic acid in Brassica campestris. Recovery of hypocotyls growth, protein and RNA levels in presence of GA. Physiol Plant. 1983,59(1):111-14. https://doi.org/10.1111/ j.1399-3054.1983.tb06580.x 
45. Groot, S. P. C., Bruinsma, J. and Karssen, C. M. The role of endogenous gibberellin in seed and fruit development of tomato: Studies with a gibberellin-deficient mutant. Physiol Plant. 1987;71(2):184-90. https://doi.org/10.1111/j.13993054.1987.tb02865.x

46. Zhang C, Tanabe K, Tamura F, Matsumoto K, Yoshida A. ${ }^{13} \mathrm{C}$ photosynthate accumulation in Japanese pear fruit during the period of rapid fruit growth is limited by the sink strength of fruit rather than by the transport capacity of the pedicel. J Exp Bot. 2008;56(420):2713-19. https://doi.org/ $10.1093 / \mathrm{jxb} / \mathrm{eri} 264$

47. Yomo H, Varner JE. Control of the formation of a-amylase and protease in cotyledons of germinating peas. Plant Physiol.

https://doi.org/10.1104/pp.51.4.708 1973;51(4):708-13.

48. Yoshida I, Hirasawa E. Gibberellin induces endopeptidse activity in detached cotyledons of Pisum sativum L. Plan Growth Regul. 1997;19:55-60. https://doi.org/10.1007/ BF00024402
Additional information

Peer review information: Plant Science Today thanks Sectional Editor and the other anonymous reviewers for their contribution to the peer review of this work.

Reprints and permissions information is available at https://horizonepublishing.com/journals/index.php/PST/open_access_policy

Publisher's Note: Horizon e-Publishing Group remains neutral with regard to jurisdictional claims in published maps and institutional affiliations.

To cite this article: Saminu N M, Muhammad Y Y. Seed storage protein changes and mobilization pattern in Bambaranut (Vigna subterranea (L.) Verdc.) during germination. Plant Science Today. 2021;8(4):1049-1056. https://doi.org/10.14719/pst.2021.8.4.1257

Plant Science Today, published by Horizon e-Publishing Group, is covered by Scopus, Web of Science, BIOSIS Previews, Clarivate Analytics, etc. See https://horizonepublishing.com/journals/index.php/PST/indexing_abstracting 